\title{
NCOA5 wt Allele
}

National Cancer Institute

\section{Source}

National Cancer Institute. NCOA5 wt Allele. NCI Thesaurus. Code C52142.

Human NCOA5 wild-type allele is located within 20q22-q13.12 and is approximately $29 \mathrm{~kb}$ in length. This allele, which encodes nuclear receptor coactivator 5 protein, plays a role in nuclear receptor-dependent transcriptional modulation. 